\title{
Opportunity and Challenges of Sweet Orange (Citrus sinensis L. Osbeck) Production in Sindhuli and Ramechhap Districts
}

\author{
Umesh Kumar Acharya $^{1^{*}}$ \& Hari Krishna Shrestha ${ }^{2}$ \\ ${ }^{I}$ National Citrus Research Program, Paripatle, Dhankuta \\ ${ }^{2}$ National Food Research Centre, Khumaltar, Lalitpur \\ "Corresponding Author's Email: umeshach@gmail.com \\ "Orcid ID: http://orcid.org/0000-0001-9179-5010
}

Received on: 30 September 2020, Revised on: 31 March 2021, Accepted on: 11 April 2021

\begin{abstract}
Household survey and focus group discussion (FGD) were carried out in year 2017/18 in Sindhuli and Ramechhap districts in order to identify scope and constraints for better sweet orange production. A semistructured questionnaire acquiring household and orchard information, production, post-harvest operation as well as marketing situation was administered in the survey of 60 and 62 house-holds in Sindhuli and Ramechhap, respectively. Prior to household survey, a FGD was carried out in each site of Sindhuli and Ramechhap to collect general information and cross check the individual response. Poor orchard management, lack of irrigation, infestation of a number of insects including fruit fly, infection of a number of diseases as well as lack of financial facilities were reported as key constraints to grow sweet orange industries in these districts. The yield of sweet orange was found less than national average yield in both survey sites. Various measures to increase production and to improve post-harvest quality of fruits have been suggested based on situation analysis.
\end{abstract}

Keywords: Fruit fly, junar, market, survey, super zone

\section{Introduction:}

Sweet orange also known as Junar (Citrus sinensis L. Osbeck) in Nepal is mostly cultivated in mid hills of Nepal (Kaini, 2013). Among 42 citrus producing districts two districts Sindhuli and Ramechhap commercially grow sweet orange (MoALD, 2018). The cultivated variety of sweet orange in those districts was reported to be of local origin (Kaini 2013). However sweet orange was believed to be introduced in Nepal by Rana regime in early $1800 \mathrm{AD}$. In the surveyed year 2017/18, the sweet orange area in Sindhuli district was 1381 with productivity of $12 \mathrm{mt} / \mathrm{ha}$. Similarly, the production area was 1100 ha with productivity of $12 \mathrm{mt} / \mathrm{ha}$ in Ramechhap district (MoALD, 2018). In
Sindhuli district, the total area of sweet orange was reported as 1381 hectare whereas that of mandarin was reported as 619 hectares. Total estimated production of sweet orange in the district was 8200 ton per annum which showed low average yield of fruits i.e. 5.94 ton per hectare. The estimated annual revenue from sweet orange was NRs. 28 crore during last fiscal year i.e. 2073/74.

The average productivity of sweet orange in these two districts was very low as compared to other sweet orange producing countries. Perceiving the importance of sweet orange, Government of Nepal has launched super zone 
and zone program under Prime Minister Agriculture Modernization Project (PMAMP) in Sindhuli and Ramechhap. To cater the need for identification of suitable sweet orange production technologies in these districts, a survey was carried out by National Citrus Research Program, Dhankuta. The survey findings would be treated as benchmark for future planning of research and development program of sweet orange. The findings would especially be important for zone and super zone offices of sweet orange to identify the bottleneck of sweet orange industries and plan the development activities accordingly.

\section{Materials and Methods:}

\section{Focus Group Discussion}

Focus group discussion was held in Khaniyakharka, Sindhuli on $15^{\text {th }}$ November 2017 in a group of 15 farmers who had their own orchards of sweet orange (Junar) and actively involved in the farming. A multi-disciplinary team of scientists comprising a socio-economist, a pomologist and a plant pathologist had interacted with the farmers by using a checklist. Another focused group discussion was held in Bhalukhop, Okhreni (Ramechhap) in a group of 12 farmers in presence of District Agriculture Development Officer, Ramechhap on $16^{\text {th }}$ November 2017. The same multidisciplinary team of scientists involved in Sindhuli had interacted with the farmers by using a similar checklist. The team had also visited different villages of Sindhuli (Ratanchura and Jalkanya) and Ramechhap (Bhangeri, Golmatar and Okhreni) to observe sweet orange production orchards.

\section{Household Survey}

One hundred twenty-two households were surveyed in two districts using a semi structured questionnaire in January 2018. This sample size was considered minimum required size to represent the population of sweet orange farmers as decided by the survey team in consultation with leader farmers. Due to limitation of man power and time available, we had decided to stick on this sample size i.e.122. Randomly selected 60 respondents from Sindhuli and 62 respondents from Ramechhap were interviewed.

A Preferencial index ranking was carried out (using formula below) to find out important diseases, insects and production issues by assigning scale value of 1-5 based on priorities set by the 122 respondents (Gautam 2018). The survey data were recorded in excel software and later analysed using R software (version R 3.4.1)

Preferencial ranking index, $\mathrm{I}_{\mathrm{imp}}=\Sigma\left(\mathrm{S}_{\mathrm{i}} \times \mathrm{f}_{\mathrm{i}} \mathrm{N}\right)$

Where, $\mathrm{I}_{\text {imp }}=$ Index of importance

$\mathrm{S}_{\mathrm{i}}=$ scale value

$\mathrm{N}=$ No. of respondents

$\mathrm{f}_{\mathrm{i}}=$ Frequency of importance given by respondents

\section{Results:}

\section{Demographic information of surveyed household in Sindhuli and Ramechhap district}

Out of 122 respondents, $81.97 \%$ were male and $18.03 \%$ were female. Among them $85.25 \%$ had studied below class 10 level, $12.2 \%$ had studied college level and $2.46 \%$ had higher degree. The age of sweet orange growing farmers ranged from 21 to 72 years. The sweet orange farming had not attracted new generation people as the average age of farmers in Sindhuli and Ramechhap was 47 and 51 years, respectively.

\section{Orchard situation}

Based on slope of the land, most of the sweet orange orchards in survey area $(54.1 \%)$ was east facing followed by north facing (27.87\%; Table 1). About two third of surveyed orchards $(66.7 \%)$ in Sindhuli district were reported east facing while in Ramechhap district the most orchards were facing north $(45.2 \%)$ followed by east (41.9\%). Ramechhap district, being in rainshadow area, orchards were north facing due to less sun shine on that face which helps retain more moisture required for sweet orange cultivation. The average age of orchard in Sindhuli was 17.5 years while that was 23 in Ramechhap with a range 1-45 years old in both districts.

Table 1. Proportion of sweet orange orchard aspect in survey area $(\%)$

\begin{tabular}{|l|c|c|c|}
\hline Aspect & Sindhuli & Ramechhap & Total \\
\hline East & 66.7 & 41.9 & 54.1 \\
\hline West & 16.7 & 11.3 & 13.93 \\
\hline North & 10 & 45.2 & 27.87 \\
\hline South & 1.7 & - & 0.82 \\
\hline Mixed & 5 & - & 3.28 \\
\hline
\end{tabular}

Source: Field Survey, 2018 
As per this study most of the surveyed orchard had loamy type soil in Sindhuli (56.67\%) and Ramechhap district (87.1\%; Table 2). A significant number of surveyed orchard in Sindhuli had sandy type (15\%) and clay type soils (13.3\%).

Table 2. Respondent's perception on soil type in survey area $(\%)$

\begin{tabular}{|l|l|l|l|}
\hline \multicolumn{1}{|c|}{ Soil type } & \multicolumn{1}{c|}{ Sindhuli } & Ramechhap & Total \\
\hline Loamy & 56.67 & 87.1 & 72.13 \\
\hline Sandy & 15 & 1.61 & 8.2 \\
\hline Clay & 13.3 & 8.84 & 9.02 \\
\hline Others & 15 & 6.45 & 10.66 \\
\hline
\end{tabular}

Source: Field Survey, 2018

\section{Planting material used}

There was an issue with quality planting materials in survey area as most of them were from nearby nurseries (Table 3). Mostly the planting materials were of seedling origin rather than grafted ones and the age of orchards were nearly 50 years in the surveyed area. Further, all of these seedlings were produced from local cultivar with only a few exceptional cases.

Table 3. Source of planting material used (\%) by the respondents

\begin{tabular}{|l|c|c|c|}
\hline Soil type & Sindhuli & Ramechhap & Total \\
\hline Own source & 15 & 1.6 & 8.2 \\
\hline Nearby nursery & 81.7 & 83.9 & 82.79 \\
\hline $\begin{array}{l}\text { Nursery form } \\
\text { another district }\end{array}$ & 0 & 1.6 & 0.82 \\
\hline $\begin{array}{l}\text { Government } \\
\text { farm }\end{array}$ & 1.7 & 6.4 & 4.1 \\
\hline No idea & 1.7 & 6.4 & 4.1 \\
\hline
\end{tabular}

Source: Field Survey, 2018

In Ramechhap, about one-fourth of surveyed orchards were established with planting materials of seedling origin whereas in Sindhuli, very few orchards were established with grafted saplings. Most of the orchards had both type saplings in Sindhuli and Ramechhap (Table 4).
Table 4. Planting materials used in surveyed area (\%)

\begin{tabular}{|l|c|c|c|}
\hline \multicolumn{1}{|c|}{ Type } & Sindhuli & Rammechhap & Both \\
\hline Seedlings & 0 & 24 & 12.3 \\
\hline Grafted & 5 & 0 & 2.5 \\
\hline Both & 85 & 76 & 80.3 \\
\hline Don't know & 10 & 0 & 4.9 \\
\hline
\end{tabular}

Source: Field Survey, 2018

\section{Cultivation practice}

Most of the surveyed orchards were established in rainfed condition in Ramechhap district (Table 5). More irrigation facilities were found in Sindhuli district as compared to Ramechhap. Farmers in Sindhuli used to irrigate up to six times during the required season (Table 6). Small farm canal and polythene pipes supplied water from small stream/springs were the most common irrigating methods in Sindhuli.

Sweet orange farmers were well aware about the importance of training and pruning of citrus tree for healthy management of their orchards. Eighty nine percent farmers from both disticts were found following pruning practice during December-January.

In both districts, respondent farmers used to apply FYM as main source of fertilizer, which was mostly taken up by intercrops rather than main junar crop. Most of the surveyed farmers had followed intercropping prcatice in their orchard (Fig. 2). Negligible amount of chemical fertilizers (urea, DAP and Potash) used to applied by farmers in both districts (Table 8). The amount of applied chemical fertilizer was far below national recommendation. Farmers in both districts were cultivating a number of crops as intercrops irrespective of the age of orchards. Mostly cereal crops were used as intercrops (50\%, Fig. 2) which could not be recommended to cultivate in the citrus orchard.

More than ninety percent orchards had irrigation facility in Sindhuli whereas only twenty three percent orchards had irrigation faciltiy in Ramechhap (Table 5).

Table 5. Availability of irrigagion facility in surveyed households (\%)

\begin{tabular}{|l|c|c|c|}
\hline Facility & Sindhuli & Ramechhap & Total \\
\hline Yes & 91.7 & 22.6 & 56.56 \\
\hline No & 8.3 & 77.4 & 43.44 \\
\hline
\end{tabular}

Source: Field Survey, 2018 
In Sindhuli, about half of the households used to irrigate only one time whereas one-fourth households used to irrigate two times per season. A few households used to irrigate their orchards up to six times per season. In Ramechhap, only a few households had irrigation facility and they used to irrigate their orchards up to two times per season (Table 6). Less number of irrigation is attributed by drought and less irrigation facility in the area. Rainwater harvest could be a best way for irrigation in such area.

Table 6. Irrigation frequency (\%) provided in sweet orange orchards in survey area

\begin{tabular}{|l|c|c|c|}
\hline Time & Sindhuli & Ramechhap & Total \\
\hline 0 & 8.3 & 77.4 & 43.44 \\
\hline 1 & 51.7 & 6.4 & 28.69 \\
\hline 2 & 26.7 & 11.3 & 18.85 \\
\hline 3 & 1.7 & - & 0.82 \\
\hline 4 & 5 & - & 2.46 \\
\hline 6 & 5 & - & 2.46 \\
\hline When needed & 1.7 & 4.8 & 0.82 \\
\hline
\end{tabular}

Source: Field Survey, 2018

In Sindhuli, one-third households were using farm canal and a similar proportion of households was using polypipes for irrigation (Table 7 ). Some of them had plastic ponds for water storage to irrigate as and when needed. In Ramechhap, some households were using polypipes whereas a few households had plastic ponds.

Table 7. Ways of irrigating (\%) sweet orange orchard in survey area

\begin{tabular}{|l|l|l|l|}
\hline Method & Sindhuli & Ramechhap & Total \\
\hline Rainfed & 8.3 & 77.4 & 42.6 \\
\hline Farm canal & 33.3 & - & 16.4 \\
\hline $\begin{array}{l}\text { Polyethelene } \\
\text { pipes }\end{array}$ & 30.3 & 14.5 & 22.1 \\
\hline Plastic ponds & 15 & 8.1 & 11.5 \\
\hline Mix method & 5 & - & 2.5 \\
\hline Others & 8.1 & - & 4.9 \\
\hline
\end{tabular}

Source: Field Survey, 2018

For manuring in orchard, about ninety percent households used to apply sole FYM in both districts (Table 8). Application of sole FYM would not be enough to fulfill the nutritional requirement of fruit trees. Very few percent households used to apply both FYM and chemical fertilizer. It showed that farmers were not aware about proper nutritional management which was most important for healthy orchard.

Table 8. Type of fertilizer use (\%) in sweet orange orchards in survey area

\begin{tabular}{|l|r|r|r|}
\hline Type & Sindhuli & Ramechhap & \multicolumn{1}{l|}{ Total } \\
\hline FYM only & 91.7 & 87 & 89.34 \\
\hline Chemical only & 1.7 & - & \\
\hline Both & 6.7 & 13 & 0.84 \\
\hline
\end{tabular}

Source: Field Survey, 2018

About ninety five percent farmers in both districts had followed intercropping prcatice in their orchard (Table 9). Most common intercrop was cereal crop which had obviously negative impact on the sweet ornage trees (Fig 1). Leguminous crops or vegetables could be grown as synergystic crops in sweet orange orchards (NCRP 2015/16).

Table 9. Intercropping practices in survey area

\begin{tabular}{|l|l|l|l|}
\hline Intercropping & Sindhuli & Ramechhap & Both \\
\hline Yes & 98.3 & 93.5 & 95.9 \\
\hline No & 1.7 & 6.4 & 4.1 \\
\hline
\end{tabular}

Source: Field Survey, 2018

Application of FYM was very less in quantity as compared to the need of fruit trees which were more than 10 years old (Table 10). Similarly, use of chemical fertilizer was negligible as compared to the requirement. The recommended dose of FYM, urea, DAP, Potash were $100 \mathrm{~kg}, 0.883 \mathrm{~kg}, 0.521 \mathrm{~kg}$, and $0.583 \mathrm{~kg}$ respectively for a ten year old tree (Acharya et al 2018). The table 10 shows that FYM application amount was about one-fourth of the requirement whereas the chemical fertilizer application amount was negligible. Inadequate nutrient supply would have adverse effect in the sweet orange orchard causing fruit drops and various diseases.

Table 10. Amount of fertilzer used in survey area (Kg/tree/year)

\begin{tabular}{|l|l|l|l|l|}
\hline Particular & FYM & Urea & DAP & Potash \\
\hline Sindhuli & 34.8 & 0.07 & 0.12 & 0.07 \\
\hline Ramechhap & 22.6 & 0.03 & 0.05 & 0.01 \\
\hline Average & 28.6 & 0.05 & 0.08 & 0.04 \\
\hline
\end{tabular}

Source: Field Survey, 2018 


\section{Intercropping in sweet orange orchard}

Most of the orchards had cereal crops as intercrop resulting negative effects on fruit trees (Fig. 1). Some orchards had vegetables as intercrop and some other orchards had a crop rotation of cereal - legume. A few orchards had cereal - oilseed and other few had cereal - vegetables as intercrops. Very few orchards had sole fruit trees without intercrop.

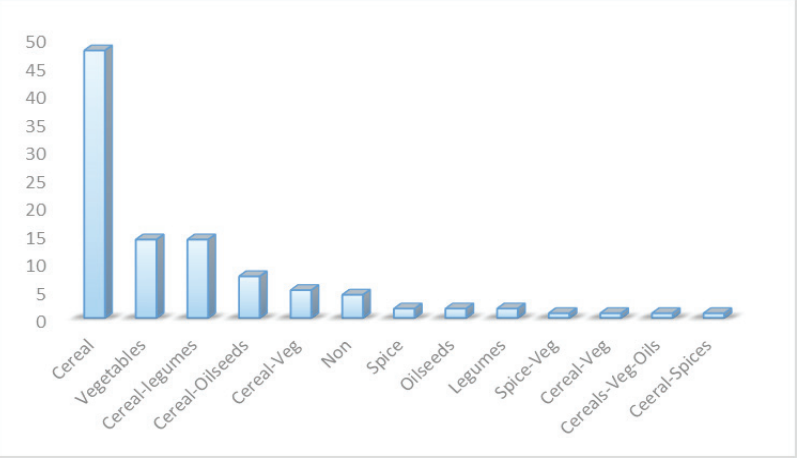

Fig 1: Percentage household intercropping various crops in sweet orange orchard

\section{Post-harvest practice}

Farmers used to start harvesting the fruits from early Kartik month and the harvesting lasts untill late Paush. Most of the farmers had practice of hand picking leaving fruit stalk intact (Table 11). About one-fifth farmers were using clipper to pick the fruits (Table12). The fruits were then carried to the nearby collection center or storage facilty using traditional bamboo basket (doko) followed by jute or plastic sacks (Table 13). These doko and sacks were the post harvest loss inducing means of transportation as there would be more physical damage caused by bruising and compaction of fruits.

Table 11. Method of fruit harvesting in survey area (\%)

\begin{tabular}{|l|l|l|l|}
\hline Harvesting & Sindhuli & Ramechhap & Both \\
\hline With stalk & 91.7 & 90.3 & 91 \\
\hline Without stalk & 8.3 & 9.7 & 9 \\
\hline
\end{tabular}

Source: Field Survey, 2018

More than ninety percent farmers in Sindhuli had practice of hand picking (twisting fruit pedicle) whereas only five percent had used clippers for fruit harvesting. Sixty one percent farmers in Ramechhap had practice of hand picking whereas thirty nine percent farmers were using clippers (Table 12).
Table 12. Harvesting means used in survey area (\%)

\begin{tabular}{lccc}
\hline Harvesting & Sindhuli & Ramechhap & Both \\
\hline By hand & 93.4 & 61 & 77.05 \\
By clipper & 5 & 39 & 22.13 \\
Both & 1.6 & 0 & 0.82 \\
\hline
\end{tabular}

Source: Field Survey, 2018

Although there was a substantial loss of fruits while using bamboo basket (doko) or other sacks, farmers were using the same for transportation. Only five percent farmers in Sindhuli were using plastic crates which could make minimum loss of fruits (Table 13). Higher cost and less durability of plastic crates might be serious constraints of using those crates for transportation.

Table 13. Methods of transporting fruit to market at survey area $(\%)$

\begin{tabular}{llll}
\hline \multicolumn{1}{c}{ Means } & Sindhuli & Ramechhap & Both \\
\hline $\begin{array}{l}\text { Bamboo basket } \\
\text { (Doko) }\end{array}$ & 88.3 & 34 & 60.66 \\
Jute Sacks & 1.7 & 66 & 34.43 \\
Plastic crates & 5 & 0 & 2.46 \\
Doko and Sacks & 3.4 & 0 & 1.64 \\
Other & 1.7 & 0 & 0.82 \\
\hline
\end{tabular}

Source: Field Survey, 2018

\section{Production and marketing}

The survey results showed that the average productivity of Ramechhap district was higher $(5952 \mathrm{~kg} / \mathrm{ha})$ than Sindhuli district (4942 kg/ha) (Fig. 2). In Ramechhap, the productivity of sweet orange ranged from 445$20040 \mathrm{~kg} / \mathrm{ha}$, while that ranged from $41-17985 \mathrm{~kg} / \mathrm{ha}$ in Sindhuli district. Farmers were earning from sweet orange as low as NRs 500 to as high as $170000 /$ - per year in both districts. Farmers used to get as low as NRs.35/ $\mathrm{kg}$ of sweet orange at farm gate and $60 / \mathrm{kg}$ at the market while the consumer price ranged around $80-150 / \mathrm{kg}$ in retail shop. About two third of the farmers used to sell their produce to the local traders at farm gate, while one third had practice of contract selling and negligible number of farmers had practice of retail selling at the 
market (Table 14). About 3\% farmers used to store their fruit produce for late season selling. However, only one farmer in Sindhuli was found having own cellar storage facility accomodating one ton quantity of fruits. Only 4\% farmers from both districts had idea about post-harvest processing products of sweet orange from which they used to prepare jam, squash, jelly and wine from the junar fruit.
Table 14. Fruit selling ways in surveyed area (\%)

\begin{tabular}{|l|l|l|l|}
\hline \multicolumn{1}{|c|}{ Method } & Sindhuli & Ramechhap & Average \\
\hline Self-selling at farm & 72.4 & 54.1 & 63.03 \\
\hline Contractor selling & 13.8 & 42.6 & 28.57 \\
\hline Middle man selling & 6.9 & 1.6 & 4.2 \\
\hline Self-selling at Market & 5.2 & 1.6 & 3.36 \\
\hline Storage & 1.7 & 0 & 0.84 \\
\hline
\end{tabular}

Source: Field Survey, 2018

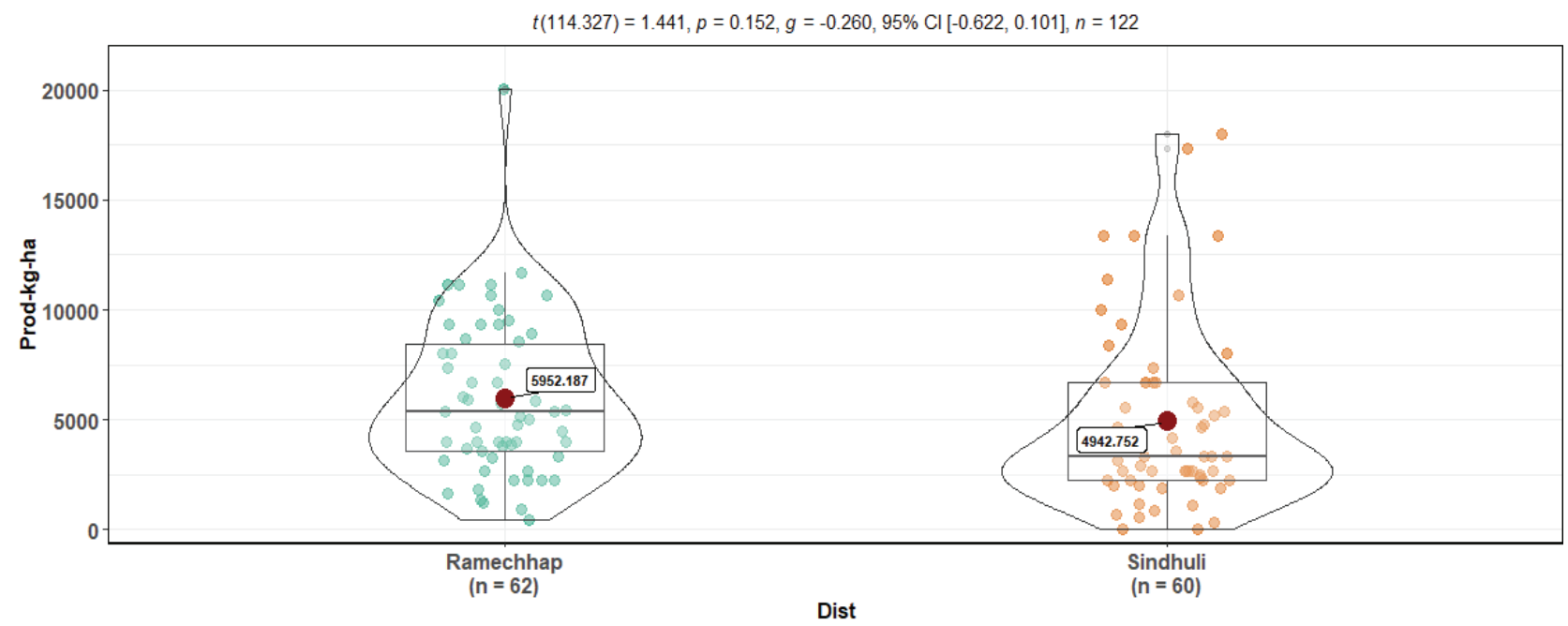

Fig 2: Sweet orange yield ( $\mathrm{Kg} / \mathrm{ha})$ differences in two surveyed districts

\section{Preference ranking of production issues and farmers need}

Based on preferencial raning among the diseases, powdery mildew accorded the highest index value of 0.93 followed by Sooty mold (0.30) and root rot (0.18). In case of insects, fruit fly was the number one trouble with index value of 0.73 followed by green stink bug (0.71), scale insect (0.23) and leaf minor (0.01). When the respondents were asked for their need to improve the junar production in the surveyed area, the preferencial index ranking for irrigation system obtained the highest value ( 0.83 ) followed by quality sapling $(0.42)$, availability of qualified technician (0.29), access to market (0.08), subsidy (0.07), availability of pesticide (0.06), technical know-how/training (0.06), road (0.01) and storage facility $(0.01)$.

\section{Discussions:}

Despite involvement of more than 33 cooperatives and numberous local govenrmental bodies (PIU Superzone, 2018), the quality fruit production was not improving in both sweet orange producing distrits (Fig 2). The FGD also confirm that involvment of too many institure and area increament in past few year is not helping on sweet orange production enhancement. The national level authority data shows the productivity as $12 \mathrm{t} / \mathrm{ha}$ (MoALD, 2018) while this survey founds the productivity was far less than the data of national authority. Similar kind of productivity situation was reported by Subedi and Acharya (2008) in Dailekh district. Regmi et al. (2000) also reported similar productivity situation in western part of Nepal. The situation has not been improved despite governmental initiation since last 25 years to make Sindhuli and Ramechhap as leading Junar producing districts which is quite distressful. This could be attributed to poor orchard management. The mismanagement problem started with use of poor planting materials that is from unknown source $(83 \%$, Table 3 ) and only use of $2.5 \%$ grafting origin (Table 4). Further $43 \%$ orchards were under rainfed system (Table 5) but 96\% farmers were adopting intercropping 
system (Table 9) with higher fertilizer demanding cereal crops (48\%, Fig. 1 ) while less use of nutrients from organic and inorganic sources (Table 8 and 10). Further the situation was worse with infestation of fruit fly (Bactocera minax), scale insect, leaf minor as well as infestation of powedery mildew, canker and root rot as reported in the preferencial ranking from this survey. However, their management with pesticide use was limited to few orchardists (Kaini 2013). Easeness to get technical knowledge was limited by a few number of technical staffs available in the local, provincial and central government institutions. Hence more awareness on orchard management need to be incorporated into the program of local government. The market price of the fresh fruit was very high as compared to farm gate price in the both surveyed district due to establishment of retail shop along the BP Highway. The lower farm gate price to whole saler could be due to faulty picking method (hand picked with twisting the fruit $77 \%$, Table 12) and transportation using bambo basket (doko, $61 \%$ Table 13) which incure more post-harvest loss. Further such fruits were sold by road side without maintaining cool chain which could be due to limited knowledge about post harvest knowledge as only 5\% respondent had idea about it. Desite recommendation on the use of imporved package of practice (Acharya et al., 2010) to imporve production of sweet orange, no availibitly of financial assistance from banks as well as lack of insurance of the crop could be other reasons for adaptation of improved practice on the orchard.

\section{Conclusions:}

The productivity of sweet orange was very low in Sindhuli and Ramechhap districts. Poor management of orchards with very less input supply was a major cause of less productivity in both districts. Production under rainfed system and use of low quality seedling is rampant. Healthy sapling production and distribution of early, mid and late season cultivars need to be promoted. Disease and pest management program as a campaign need to be implemented by government agencies. Further the faulty intercropping practice need to be correccted with dessimination of proper knowledge. There was still scope to revive the poor production of orchards as some of the progressive farmers had still good condition orchard with better management and higher productivity.

\section{Acknowledgements:}

The authors would like acknowledge Prime-minister Agricultural Modernization Project under Ministry of Agricultural Livestock Development for providing research grant to conduct this study. We also acknowledge Mr Balram Basnet and Mr. Chandra Chaulagain for their assistance on household survey.

\section{Declaration of conflict of interest and ethical approval:}

UK Acharya was involved in designing the household questionnaire and writing the manuscript. HK Shrestha was involved in conducting FGD and participated in writing the manuscript. All the authors have read the manuscript before submitting to the Journal of Nepalese Horticulture and declares that there is no competing interest regarding the current manuscript.

\section{References:}

Acharya, U.K., Gautam, I.P., Subedi, G.D, Devkota, K. (2010). Rejuvination of declining mandarin orange orchard with imporved management practice in mid-western hills of Nepal. Agricultural Development Journal, Directorate of Agricultural Training, Department of Agriculture, Hariharbhawan, Kathmandu, pp 24-29.

Acharya, U.K., PAkka, R, Adhikari, D.R., Joshi, S.L. (2018). Commercail Citrus Production Technology. National Citrus Research Program, Paripatle, Dhankuta (in Nepali language)

Gautam, E. (2018). Survey and monitoring of chinese citrus fly (Bactrocera minax) in sweet orange in sindhuli district, Nepal. (Unpublished Research Report), Agriculture and Forestry University, Rampur, Chitwan (Unpublished)

Kaini, B.R. (2013). Sweet orange production and postharvest management. Central Junar Cooperative Fedaration, Tinkune, Kathmanadu.

MOAD. (2018). Statistical information on Nepalese agriculture. Government of Nepal, Ministry of Agricultural Development, Agri-Business Promotion and Statistics Division, Statistics Section, Singha Durbar, Kathmandu, Nepal. 
NCRP (2015/16). Annual Reports (2072/73). National

Citrus Research Program, Nepal Agricultural Reseach Council, Paripatle, Dhankuta.

PIU (2018). Annual Report (2018) Program Implementing Unit, Junar Superzone, Prime minister Agriculture Modernization Program, Sindhuli.

Regmi, H.N.,Gurung, D.B., Adhikari, C. (2000) Survey in fruit drop in mandarin under mid hills of mid and far western hills of Nepal. HARP Reports, Agricultural Reseaerch Station, Nepal Agricultural Reseach Council, Dailekh, Nepal.

Sugedi, G.D. \& Acharya, U.K. (2008). Management of Citrus decline and its rejuvination strategites for declining orchards in Dailekh. Paper presented in $5^{\text {th }}$ National Conferene in Science and Technology, 10-12 November 2008, Khmulaltar, Lalitpur. 